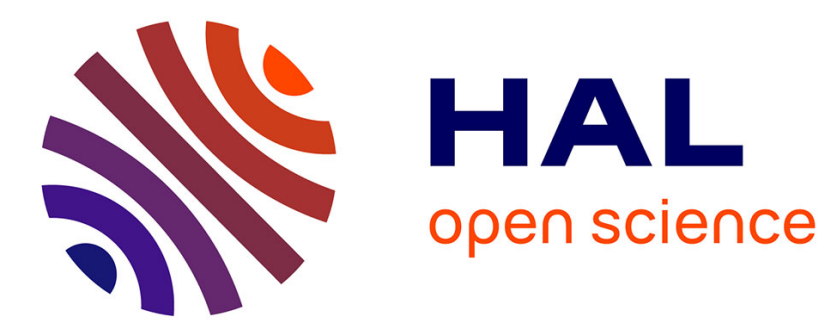

\title{
A numerical modelling technique for geosynthetics validated on a cavity model test
}

B.F.G. Tano, Gabriel Stoltz, N. Touze-Foltz, D. Dias, F. Olivier

\section{To cite this version:}

B.F.G. Tano, Gabriel Stoltz, N. Touze-Foltz, D. Dias, F. Olivier. A numerical modelling technique for geosynthetics validated on a cavity model test. Geotextiles and Geomembranes, 2017, 45 (4), pp.339-349. 10.1016/j.geotexmem.2017.04.006 . hal-01739604

\section{HAL Id: hal-01739604 https://hal.science/hal-01739604}

Submitted on 21 Mar 2018

HAL is a multi-disciplinary open access archive for the deposit and dissemination of scientific research documents, whether they are published or not. The documents may come from teaching and research institutions in France or abroad, or from public or private research centers.
L'archive ouverte pluridisciplinaire HAL, est destinée au dépôt et à la diffusion de documents scientifiques de niveau recherche, publiés ou non, émanant des établissements d'enseignement et de recherche français ou étrangers, des laboratoires publics ou privés. 
1 A numerical modelling technique for geosynthetics validated on a cavity model test

3 Corresponding author:

4 Tano, Bekoin Francis Guillaume $\mathrm{a}^{\mathrm{a}, \mathrm{c}, \mathrm{d}}$ - francis.tano@ecogeos.fr, francis.tano@irstea.fr /

$5+33140966236,+33628359759$

6 Co-authors:

7 Stoltz, Guillaume ${ }^{\mathrm{b}}$ - guillaume.stoltz@irstea.fr / +33140966048

8 Touze-Foltz, Nathalie ${ }^{\mathrm{a}}$ - nathalie.touze@irstea.fr / +33140966039

9 Dias, Daniel ${ }^{\mathrm{e}}$ - daniel.dias@ ujf-grenoble.fr / +33476827931

10 Olivier, Franck ${ }^{c}$ - franck.olivier@ecogeos.fr / +33321155570

12 Organization:

$13{ }^{a}$ Irstea Antony, 1 rue Pierre Gilles de Gennes, 92760 Antony, France

$14{ }^{\mathrm{b}}$ Irstea Aix-En-Provence, 3275 Route Cézanne, CS 4006113182 Aix-en-Provence, France

$15{ }^{\mathrm{c}}$ Ecogeos, 5, rue du jeu de Paume, 62000 Arras, France

$16{ }^{\mathrm{d}}$ Lthe, Grenoble Alpes University, OSUG B, Domaine universitaire, BP 53, 38041 Grenoble

17 cedex 09, France

18 e 3SR, Polytech Grenoble Alpes University, Domaine Universitaire BP 53, 38041 Grenoble 09

19 Cedex 09, France 


\section{ABSTRACT}

22 Numerical modelling approaches can aid in designing geotechnical constructions involving

23 geosynthetics. However, the reliability of numerical results depends on how the model is

24 developed, the constitutive model, and the set of parameters used. By comparing the numerical

25 results with experiment, the present work verifies a numerical modelling technique developed to

26 model multilayered geosynthetic lining systems for landfills. The numerical modelling technique

27 involves strain softening at interfaces and allows the axial stiffness of the geosynthetics to evolve

28 as a function of strain. This work focuses on a two-dimensional finite-difference model, which is

29 used to simulate three types of experimental tests: conventional uniaxial tensile tests, direct shear

30 tests, and a large-scale test that was used to assess the overall mechanical behaviour of a

31 reinforced geosynthetic system that spanned over a cavity. This reinforced geosynthetic system

32 consisted of a $50 \mathrm{kN} / \mathrm{m}$ polyvinyl alcohol geogrid reinforcement embedded in a layer of sand, a

33 geosynthetic clay liner, a high-density polyethylene geomembrane, and a non-woven needle-

34 punched geotextile. The uniaxial tensile tests, direct shear tests, and the large-scale test were

35 numerically modelled and the numerical results were compared with experimental results. The

36 results of the numerical modelling technique presented very closely match the results of the three

37 experimental tests, which indicates that the numerical model correctly predicted the measured

38 data.

40 Keywords: Geosynthetics, numerical modelling, tensile test, direct shear test, large-scale test,

41 strains, shear displacements 


\section{NOTATIONS}

$44 \quad K_{s} \quad$ Interface shear stiffness

$45 \quad K_{n} \quad$ Interface normal stiffness

$46 \quad c \quad$ Cohesion

$47 \emptyset_{\text {peak }} \quad$ Peak friction angle

$48 \emptyset_{\text {res }} \quad$ Residual friction angle

$49 \quad$ Sand unit weight

$50 E \quad$ Sand elastic modulus

$51 v \quad$ Sand Poisson ratio

$52 \quad D_{\min } \quad$ Minimum diameter of sand particles

$53 D_{\max } \quad$ Maximum diameter of sand particles

55 ABBREVIATIONS

56 GMB Geomembrane

57 GGR Geogrid

58 GTX Geotextile

59 GCL Geosynthetic clay liner

60 PVA Polyvinyl alcohol

61 HDPE High-density polyethylene

62 UTT Uniaxial tensile test

63 DST Direct shear test

64 LSTA Large-scale test apparatus

65 


\section{INTRODUCTION}

68 Geotechnical constructions that involve geosynthetics, such as landfills, are traditionally designed

69 by using limit equilibrium methods (Giroud, 1989, Koerner and Hwu, 1991). However, these

70 methods cannot be used to assess the integrity (e.g., strain or tensile forces) (Long et al., 1994) of

71 the construction components and do not consider whether stresses are compatible with strains and

72 displacements (Villard et al., 1999). As an alternative, such constructions may be designed by

73 using numerical modelling methods (Fowmes et al., 2008); these methods not only account for

74 the above-mentioned aspects but also account for the multiple interactions between

75 geosynthetics.

76 Numerical modelling techniques are becoming ever more sophisticated because today's software

77 allows designers to consider the key aspects of the mechanical characteristics of geosynthetics

78 (e.g., the nonlinear stiffness) and of the interfaces (e.g., strain softening). However, the reliability

79 of such numerical results depends on the numerical modelling technique used, which in turn rests

80 upon how the model is developed, the constitutive model, and the set of parameters used.

81 Whichever numerical modelling technique is used, questions exist with respect to (i) the

82 relevance of the numerical modelling technique and therefore (ii) the reliability of the numerical

83 results. Consequently, to answer such questions, numerical results should be confirmed by

84 comparing them with experimental data. In the context of landfills, and particularly for piggy-

85 back landfill expansions where a new landfill is built over an older one, such verification is

86 essential because of the interactions between the various materials, such as clay, sand, gravel,

87 geosynthetic, and waste (Tano and Olivier, 2014). 
89 Unfortunately, limited studies that addressed the comparison of the experimental behaviour of

90 multilayered geosynthetic lining systems with that predicted by numerical models are available

91 (Fowmes et al., 2008). To the best of our knowledge, only three studies (Villard et al. (1999),

92 Fowmes et al. (2008) and Zamara et al. (2014)) compare experimental results of multilayered

93 geosynthetics with numerical results of models of landfill lining systems.

94 This work aims to verify a numerical modelling technique by comparing it with three

95 experimental tests: a tensile test, a direct-shear test, and a large-scale large test. These tests were

96 developed to assess the mechanical behaviour of a reinforced geosynthetic lining system.

97 Prior to discussing the details of the verification process, the previous studies of Villard et al.

98 (1999), Fowmes et al. (2008) and Zamara et al. (2014) are further discussed in the following

99 section. The benefits and limitations of these studies provide a framework for the present study

100 and lead us to develop a new modelling technique.

101

\section{2. BACKGROUND}

103 Villard et al. (1999) applied finite-element modelling to describe a veneer cover of a landfill and

104 to better understand the distribution of forces and strains within a geotextile (GTX) and

105 geomembrane (GMB) placed at the bottom and on side slopes of the landfill. The forces within

106 the GTX were measured by force sensors positioned at the top of the slope. A cable-type

107 displacement (extensometer wires) was used to measure the geosynthetic displacements and then

108 the strains were calculated from the differential displacements obtained between two consecutive

109 measurement marks on the geosynthetic. The numerical model used the Mohr-Coulomb failure

110 criterion with single shear strength to model the interfaces and assumed a linear elastic behaviour 
111 for the various geosynthetics. The numerical results (displacements, strains and tensions) were

112 then compared with the measured results obtained at the instrumented site.

113 Although Villard et al. (1999) considered that their model produced results that were, on the

114 whole, satisfactorily consistent with experiment, discrepancies appeared between trends and

115 between the strains, forces, and displacements obtained numerically and by experiment. As an

116 example, the strains calculated by applying the numerical model to the section of slope where the

117 GTX was not covered by the granular layer were constant whereas the experimentally determined

118 strains increased along this slope. The authors attribute these discrepancies to differences in

119 displacement measurements. Moreover, at the top of the geosynthetic, the simulated

120 displacements differed from the measured displacements. Villard et al. (1999) concluded that

121 these differences were probably due to the system that fastened the geosynthetic to the top of the

122 slope interfering with the measurements. In addition, the calculated and measured strains at the

123 nonloaded part of the slope differed significantly, which the authors attributed to faulty operation

124 of the measuring devices or to insufficient stabilization time.

126 Fowmes et al. (2008) used a finite-difference method to numerically model the mechanical

127 behaviour of a two-layered geosynthetic (GTX and GMB) lining system subjected to down-drag

128 forces from synthetic waste in a large-scale test. The relative displacement of the GMB and of the

129 GTX was measured by using extensometer wires, and the forces within the GMB were measured

130 by using tensile load cells. The numerical model used the Mohr-Coulomb failure criterion with a

131 displacement-dependent limiting shear strength (i.e., strain softening) to model the behaviour of

132 the interfaces between the geosynthetics. Fowmes et al. (2008) used a constant 2\% strain secant

133 modulus to model the various geosynthetics. However, they noticed that the use of a $2 \%$ modulus 
134 in the design could lead to an overestimate of the material stiffness for strains in excess of $2 \%$. To

135 verify the numerical modelling technique, the results of the numerical calculations (strains and

136 relative shear displacements at interfaces) were compared with measurements.

137 Fowmes et al. (2008) concluded that some discrepancies existed between the measured and the

138 numerically modelled results, which they attributed to simplifications in modelling the axial

139 behaviour of the geosynthetics and in the constitutive model used to represent the synthetic

140 waste. In fact, the displacements of the GMB were underestimated by the numerical model, as

141 revealed by comparison with the large-scale test. This underestimation thus led to the

142 underestimation of the extension of the GMB. They attributed this discrepancy to the fact that the

$1432 \%$ strain secant modulus used underestimated the tensile strength at the relevant strains in their

144 investigation. Overall, Fowmes et al. (2008) concluded that their numerical model (strain-

145 softening characteristics of interfaces) and application methodology were valid.

146 More recently, Zamara et al. (2014) used the numerical model developed by Fowmes et al.

147 (2008) for strain-softening behaviour at interfaces to investigate the mechanical performance of a

148 multilayer-lining (GTX and GMB) system on a landfill slope. This site was monitored, which

149 allowed the measured displacements and strains of the geosynthetics to be compared with the

150 numerical results.

151 Zamara et al. (2014) claim that their model replicates the behaviour of the GTX at the lower part

152 of the slope. However, the correlation between (i) the measured displacements and strains and (ii)

153 the modelled displacements and strains was faulty. For example, the numerical model gave

154 compressive strains for the toe section throughout the cell-filling stages, whereas tension in this

155 section was measured on site. The authors concluded that this discrepancy is related to significant

156 displacement of the GMB at the toe of the slope due to the presence of a compressible shredded- 
157 tire basal drainage layer at the toe of the slope. Zamara et al. (2014) also numerically modeled the

158 lining system of the landfill slope by using a basic approach that does not account for the strain-

159 softening behaviour of interfaces. The results were inconsistent with the measurements,

160 especially for the GTX displacements. They also reported that the geotextile did not deform in a

161 manner modelled. Overall, Zamara et al. (2014) recognized that the verification of the numerical

162 modelling technique that they used would benefit from more monitoring data.

163

164 None of the previous studies consider the nonlinear axial stiffness of the geosynthetics in

165 modelling the interactions between these geosynthetics in the lining system. However, the stress-

166 strain response of geosynthetics is typically nonlinear (Giroud, 1994, Wesseloo et al., 2004, Tano

167 et al., 2016a), which means that the axial stiffness (e.g., the modulus) of the geosynthetic evolves

168 as a function of strain. Thus, neglecting the true characteristics of the geosynthetics could lead to

169 inaccuracies and discrepancies, as exemplified in the studies just mentioned.

170 For a more rigorous numerical analysis, Tano et al. (2016a) proposed a numerical modelling

171 technique based on the following five criteria: all geosynthetic interfaces in the lining system are

172 modelled [criterion 1 (CR1)], the staged construction or evolution of the waste properties

173 depends on depth or stress (CR2), the strain softening occurs at interfaces between geosynthetics

174 (CR3), geosynthetic compressive characteristics differ from the tensile characteristics (CR4), and

175 the geosynthetic has nonlinear axial stiffness (CR5). However, Tano et al. (2016a) did not

176 compare their numerical results with experimental results.

177 To correct this shortcoming, the present work verifies this numerical modelling technique by

178 comparing its results with experiment. 
179 These experimental tests include tensile tests and direct-shear tests, which are treated as index

180 tests throughout this paper. The numerical results are also compared with the results of a large-

181 scale $(2 \mathrm{~m} \times 1 \mathrm{~m} \times 0.5 \mathrm{~m})$ test that was developed to assess the mechanical behaviour of a

182 multilayered-lining system that spans over a cavity. This lining system includes a polyvinyl

183 alcohol geogrid (PVA GGR) reinforcement embedded in a sand layer, a geosynthetic clay liner, a

184 high density polyethylene (HDPE) GMB, and a nonwoven needle-punched GTX. For numerical

185 modelling, a two-dimensional (2D) finite-difference program was used; however, CR2 was not

186 addressed in this study because the experiments did not include waste.

187 In the following sections, the three testing devices (tensile test, direct-shear test, and large-scale 188 test) and the various materials used and their properties are presented. Next, the numerical

189 modelling technique is fully described, following which the experimental results are compared

190 with numerical results.

191

\section{$1923 . \quad$ TESTING DEVICES}

$194 \quad 3.1 \quad$ Uniaxial tensile test device

196 The UTT is a simple test used to assess tensile behaviour of a material. Geosynthetic

197 manufacturers generally systematically subject all products to UTTs to determine their quality.

198 However, complete tensile curves are rarely provided. Therefore, the authors performed

199 additional tensile tests to obtain the complete tensile curves. In these tests, a geosynthetic

200 specimen is subjected to a constant tensile deformation rate along a given axis and the resulting

201 forces and strains within the geosynthetic are recorded. Prior to the test, the specimens prepared 
202 according to the standard NF EN ISO 9862 (AFNOR, 2005a) were clamped in the tension

203 machine grips, as shown in Figure 1. For reliable measurements, five specimens of each

204 geosynthetic were subjected to uniaxial tests. The tensile tests used a strain rate of $10 \% / \mathrm{min}$., and

205 the strains and forces were measured by using a video-camera extensometer and a force sensor

206 within the upper tension jaw, respectively.

207 All tests on GMB specimens were performed according to the standard NF EN ISO 10319

208 (AFNOR, 2008) and the tests on GTX, GCL, and GGR specimens were performed according to

209 the standard NF EN 12311-2 (AFNOR, 2013).

2113.2 Direct shear test device

213 The DST is a common laboratory test used to determine the shear-strength parameters of

214 interfaces and materials. The DST device measures the shear strength under high confining stress,

215 typically up to $150 \mathrm{kPa}$. In the present study, the authors used a 0,3 $\mathrm{m} \times 0,3 \mathrm{~m}$ test device (Figure

216 1b). Three specimens of each material were tested under three normal stresses (50, 100, and 150

$217 \mathrm{kPa}$ ). To assess the shear strength of interfaces between geosynthetics, the first geosynthetic

218 sample was fixed to a horizontal plate, and the second geosynthetic sample was mounted on the

219 lower face of the test box filled with sand. Because the GGR is meshed, the procedure as

220 previously described may lead to unreliable measurements if used to assess the shear

221 characteristics of the contact between GGRs and mineral materials (e.g., sand). In fact, the shear

222 strength of the GGR-sand interface is due to several addition mechanisms, such as the frictional

223 resistance at the ribs and nodes, the bearing resistance at transverse ribs, and the interlocking of

224 aggregates (Jewell et al., 1984). 
225 Here, the procedure used for the GGR was modified to consider such mechanisms. A three-

226 dimensional geocomposite filled with sand was added at the horizontal plate, so the transverse

227 ribs should provide bearing resistance and the aggregated should interlock. Finally, a shear rate of

$2281 \mathrm{~mm} / \mathrm{min}$. was imposed on the sample during the tests by using the jack, as shown in Figure 2.

$230 \quad 3.3 \quad$ Large-scale test apparatus to simulate cavity

232 This work used a LSTA developed to simulate the mechanical characteristics of a reinforced

233 geosynthetic system that spans over a cavity. The LSTA is parallelepiped in shape (Figure 3) and

234 has internal dimensions of $2.0 \mathrm{~m} \times 1.0 \mathrm{~m} \times 0.5 \mathrm{~m}$. The principle of this large-scale test consists of 235 applying a spatially uniform pressure over a reinforced geosynthetic system that bridges a 0.5-m236 wide rectangular cavity.

237 The reinforced geosynthetic system is considered to reasonably represent the piggyback landfill-

238 lining system. This lining system often includes, from top to bottom, a GTX, a GMB, a GCL, and

239 a GGR reinforcement (Tano et al., 2015) embedded in a dense material. Sand was also added

240 within the LSTA as a subgrade for the lining system and to simulate the mineral drainage layer

241 generally installed above the GTX. The full properties of these geosynthetics and materials are

242 presented in the following section.

243 A vertical load was applied by filling a flexible bladder with water. The pressure applied at the

244 top of the LSTA via the bladder was controlled by a microprocessor-controlled pressure gauge.

245 Foil microstrain gauges (MSGs) with a linear pattern (EP-8-40CBY-120) were also used to

246 measure strains within the GGR and the GMB. The effect of the adhesive on the tensile strength 
247 of these geosynthetics was assessed through a rigorous calibration procedure, and all raw MSG

248 measurements were corrected for strains without the influence of the adhesive.

\section{MATERIAL, GEOSYNTHETIC AND INTERFACE PROPERTIES}

252 This study considers a lining system made of a GTX, a GMB, a geosynthetic clay liner (GCL), 253 and a GGR reinforcement embedded in a dense material. Sand was used to simulate this dense 254 material. The full properties of these geosynthetics, materials, and of the interfaces between the 255 various materials are presented below.

\subsection{Sand}

Hostun sand (Girout et al., 2014, Lajevardi et al., 2014) was used as a subgrade for the lining

260 system and to simulate the drainage layer above the GTX in the large-scale test apparatus

261 (LSTA). This sand layer also ensured that the load was uniformly distributed at the top surface of

262 the LSTA. The sand was dried and sieved to obtain a particle-size distribution ranging from 0.6

263 to $1.6 \mathrm{~mm}$. Direct shear tests (DSTs; see Sec. 3.2) performed on the sand under normal stresses of

26450,100 , and $150 \mathrm{kPa}$, reveal a peak (residual) friction angle of $35.2^{\circ}\left(33.8^{\circ}\right)$ and zero cohesion.

265 The properties of the Hostun sand used in the LSTA are grouped in These properties are the unit

266 weight $\gamma$, the elastic modulus $E$, the Poisson ratio $v$, the cohesion $c$, the peak friction angle $\emptyset_{\text {peak }}$,

267 the residual friction angle $\emptyset_{\text {res }}$, and the minimum and maximum particle diameters $\left(D_{\min }\right.$ and

$\left.268 D_{\max }\right)$. In situ density tests were also conducted within the LSTA. This leaded to an in-situ mean unit weight of $14 \mathrm{kN} / \mathrm{m}^{3}$. As the elastic modulus of uniform medium sand can vary from 30 to 50 
270 MPa (Kezdi, 1974, Prat et al., 1995, Obrzud and Truty, 2012), a low value of 30 MPa was

271 considered in this study since the sand was laid without specific compaction. As regards the

272 Poisson ration $v$, Hicher (1998) shows that a value of 0.23 could be considered for a well graded

273 Hostun sand. In this study, a value of 0.25 close to 0.23 was considered. Finally $D_{\min }$ and $D_{\max }$

274 was determined using the standard NF P94-056 (AFNOR, 1996).

$276 \quad 4.2$ Geosynthetics

278 For this study, four different geosynthetics were used for the experiments. These are, from top to

279 bottom, a nonwoven polypropylene GTX, a HDPE GMB, an un-hydrated sodium bentonite GCL, 280 and a PVA GGR.

281 Five uniaxial tensile tests (UTTs; see Sec. 3.1and Figure 1a) were performed on each of the 282 various geosynthetics. All these tests were performed on-air without confining loads and at a 283 constant temperature of $22^{\circ} \mathrm{C}$ in a temperature controlled room (laboratory) as required by the 284 existing standards. Rectangular specimens $(0.05 \mathrm{~m} \times 0.2 \mathrm{~m})$ were used for the GTX and GCL 285 according to the international standard NF EN ISO 10319 (AFNOR, 2008). Larger specimens $286(0.2 \mathrm{~m} \times 0.1 \mathrm{~m})$ were used for the GGR because of their ribs and nodes. For the GMB, the 287 standard NF EN 12311-2 (AFNOR, 2013) was used to assess the uniaxial tensile behaviour. The 288 full tensile curves of the four geosynthetics are given in Figure 4a (GMB and GGR) and Figure $2894 \mathrm{~b}$ (GCL and GTX). In Figure 4, data relating to the numerical simulations will be further 290 discussed in section 6.1.

291 To take into account for the non-linear stress-strain behaviour of the geosynthetics, a user-coded 292 piecewise "modulus-strain" relationship was used so that the modulus of the geosynthetic can 
293 vary with strain. These tensile axial moduli derived from the full tensile curves of the various

294 geosynthetics are shown in Figure 4. These sets of parameter were defined based on the tangent

295 modulus at each strain level. In addition, Table 1 summarizes the main properties of these

296 geosynthetics. These properties concern the thickness, the mass per unit area, the machine tensile

297 strength, the strain as a function of tensile strength, and the secant modulus at $1 \%$ strain. The

298 thickness was determined using the standard NF EN 1849-1/2 (AFNOR, 2010) for the GMB and

299 the standard NF EN ISO 9863-1 (AFNOR, 2016a) for the GTX and other geosynthetics. As

300 regards the mass per unit area, the standards NF EN 1849-1/2 (AFNOR, 2010), NF EN 14196

301 (AFNOR, 2016b) and NF EN ISO 9864 (AFNOR, 2005b) were used for the GMB, the GCL and

302 the GTX and the GGR respectively.

$304 \quad 4.3 \quad$ Interfaces

306 Because the LSTA included four geosynthetics, interaction between these geosynthetics occurred 307 across the following six interfaces:

$308 \quad-\quad$ Interface I1: between the sand layer at the top of the LSTA and the underlying GTX;

309 - Interface I2: between the GTX and the underlying GMB;

310 - Interface I3: between the GMB and the underlying GCL;

$311 \quad$ - Interface I4: between the overlying GCL and the sand layer at bottom of the LSTA, which 312 is assumed to be a subgrade layer;

313 - Interfaces I5 and I6: the upper and lower interface, respectively, between the GGR and 314 the sand layer in which it was located. 
315 Furthermore, the shear strengths of these interfaces were assessed by using DSTs (see Sec.

316 3.2and Figure 2). As previously discussed, the DST procedure used for the GGR-sand interfaces

317 was modified to account for the bearing resistance at the transverse ribs and the interlocking of

318 aggregates.

319 Figure 6 shows the shear stress versus displacement curves obtained at 50, 100 and $150 \mathrm{kPa}$ of

320 normal stresses for the six interfaces I1, I2, I3, I4, I5 and I6. In Figure 6, data relating to the

321 numerical simulations will be further discussed in section 6.2.

322 Table 1 summarizes all the properties of the interfaces derived from these the shear stress versus

323 displacement curves. These properties are shear stiffness $K_{s}$, normal stiffness $K_{n}$, cohesion $c$,

324 peak $\emptyset_{\text {peak }}$, and residual friction angle $\emptyset_{\text {res }} . K_{s}$ was calculated as the average of the three slopes

325 of the initial part of the three shear stress versus displacement curves at 50,100 and $150 \mathrm{kPa}$ of

326 normal stresses. The initial part of the shear stress versus displacement curves concerned the

327 displacements between $0 \mathrm{~mm}$ and the peak value. A constant value of $K_{S}$ was used for each

328 interface. Before the peak, the shear displacements are directly controlled by $K_{s}$ and the

329 incremental relative shear stresses. Then the Mohr-Coulomb shear-strength criterion limits the

330 shear stress applied to each interface.

331 Concerning $K_{n}$, as recommended by Itasca (2005) and Fowmes et al. (2008), an arbitrarily large

332 value was considered to avoid node interpenetration during computation. A value of $100 \mathrm{MPa}$

333 was considered following previous studies (Tano et al., 2016a, Tano et al., 2016b). Moreover,

334 zero cohesion was assigned to all interfaces because the geosynthetic interfaces are assumed to

335 have zero shear resistance when there is no confining pressure.

336 Figure 7a (I4, I5, and I6) and Figure 7Erreur ! Source du renvoi introuvable.b (I2 and I3) show

337 the evolution of the mobilized friction angle (i.e., shear strength) that was considered for the 
338 numerical modelling. The strain softening behaviour of interfaces was simulated using

339 displacement-dependant limiting shear strength values. During computation, the shear strength

340 was selected from piecewise tabulated relationships (e.g. friction angle values versus

341 displacements relationship plotted in Figure $7 \mathrm{c}$ and Figure 7d ). The peak and residual values of

342 the friction angles are given in Table 1.

343 The following section gives the details of the numerical modelling technique used in this study.

345 5. NUMERICAL MODELLING TECHNIQUE

347 As mentioned in section 2, Tano et al. (2016a) proposed a numerical model technique to simulate

348 the behaviour of a multilayered geosynthetic lining system in the context of piggy-back landfill

349 expansions. This technique was based on five criteria (CR1 to CR5). In the present study, the

350 authors use this same numerical modelling technique (Tano et al., 2016a) to model the three

351 experimental tests (UTT, DST, and LSTA). However, CR2 is not considered herein because none

352 of the three experimental tests included waste. Moreover, even were CR3 considered, it is of no

353 importance in this study because all the three experimental tests led to an overall tension (not

354 compression) in the geosynthetics.

356 The numerical modelling of these three experimental tests was implemented by using the 2D

357 finite-difference program Fast Lagrangian Analysis of Continua (FLAC 2D V.7). This program

358 allows users to consider multilayered geosynthetic interactions while modelling structural

359 elements and interfaces with a nonlinear stress-strain law (Tano et al., 2016a). Several authors

360 [e.g., Byrne (1994), Connell (2002), Jones and Dixon (2005), Fowmes et al. (2005b), Zhu et al. 
361 (2009), Chen et al. (2009b), Zamara et al. (2014)] have used this program to model complex

362 geosynthetic interactions.

364 The procedure used to consider such particularities (e.g. the strain softening behaviour of 365 interfaces and the nonlinear axial stiffness of geosynthetics) and to verify the numerical model by

366 comparison with experimental tests is outlined in the flowchart of Figure 8. Prior to the

367 calculations, four specific subroutines codes were developed by using the FISH programming

368 language, which is embedded in the FLAC software. The first FISH code modeled each

369 geosynthetic as a concatenation of several structural elements to allow the properties of each

370 individual structural element to be varied independently of the other parts of the geosynthetic and

371 as a function of strain. A similar FISH code was developed to model the various interfaces to

372 allow strength at each interface to soften independently. The two other FISH codes were

373 developed and used within the program to implement strain softening at the interfaces and to

374 update the geosynthetic axial stiffness as a function of strain. Each FISH code has already been

375 used in a previous study (Tano et al., 2016a), but the results were not verify by comparison with

376 experimental tests.

378 The experimental verification of the numerical modelling technique involved the following three 379 steps (Figure 8):

380 - Step 1: The four UTTs conducted on the GMB, GGR, GCL, and GTX were first $381 \quad$ numerically modeled based on the axial modulus vs strain curves shown in Erreur !

382 Source du renvoi introuvable.a and Erreur ! Source du renvoi introuvable.b. The 
tensile forces and strains obtained from the numerical model were compared with those obtained by experiment for each of the four geosynthetics.

- Step 2: The DSTs conducted on the six interfaces (I1-I6) were also numerically modelled based on the dependence of the friction angle on relative shear displacement (see

\section{Erreur ! Source du renvoi introuvable.c andErreur ! Source du renvoi} are compared with the results of the numerical simulation of the six interfaces. numerical modelling technique was determined by using the LSTA. This large-scale test, which involved multiple interactions between the four geosynthetics and a mechanical load above a cavity, was also numerical modelled. Here, the sand within the LSTA was modelled by using a rectangular mesh that becomes finer as it nears the geosynthetic contacts. The mesh consists of 2500 volume elements (zones), each having a size between $0.02 \mathrm{~m} \times 0.025 \mathrm{~m}$ and $0.02 \mathrm{~m} \times 0.01 \mathrm{~m}$. At the lower side of the LSTA, fixed nodal displacements were imposed. At the sides of the model, the horizontal displacements were geosynthetic layers in the model were represented by structural beam elements, which can reproduce the membrane effect with zero inertia. These structural elements are the only structural elements in FLAC 2D that allow direct interaction between two geosynthetics. Next, the overall deformed shape and mechanical behaviour of the reinforced geosynthetic system observed in the LSTA were compared with the results of the compared with the strains measured with the MSGs. 
406 All of the comparisons in steps 1 to 3 are fully discussed in the following sections.

\section{NUMERICAL MODELLING VERSUS EXPERIMENTAL RESULTS}

410 This section compares the results of numerical modelling with experimental results and discusses

411 these comparisons for the three experimental tests (UTTs, DSTs, and LSTA).

\subsection{Uniaxial tensile tests}

415 Figure 4 compares the tensile curves measured by UTTs and with curves obtained by using the

416 numerical modelling technique. The tensile curves for the GGR and the GMB appear in Figure 4a

417 and those of the GTX and GCL appear in Figure 4b. The experimental and numerical results are 418 given in Table 2 for $2 \%$ and $4 \%$ strain.

420 The results reported in Figure 4 and Table 2 provide clear evidence that the numerical model 421 provides accurate results for all the geosynthetics. For the GMB, which exhibits the most 422 nonlinear behaviour (i.e., significant curvature in the plot of tensile force vs strain), the strains 423 and forces obtained by using the numerical model are very close to the measured values. For 424 example, at $4 \%$ strain, the measured force within the GMB was $29.6 \mathrm{kN} / \mathrm{m}$ and the calculated 425 force was $29.0 \mathrm{kN} / \mathrm{m}$; a difference of only $0.6 \mathrm{kN} / \mathrm{m}(-2.0 \%)$. Again at $4 \%$ strain, the measured 426 force within the GGR was $38.6 \mathrm{kN}$ and the calculated force was $37.9 \mathrm{kN}$, a difference of only 0.7 $427 \mathrm{kN} / \mathrm{m}(-1.8 \%)$. This excellent consistency between the measured and calculated forces and 428 strains occurred for all four geosynthetics. These results demonstrate that the numerical 
429 modelling technique the FISH codes that were developed to consider the evolution of the axial

430 stiffness of geosynthetics in the numerical model, properly models the tensile behaviour of

431 geosynthetics.

432

$433 \quad 6.2$ Direct shear tests

435 This section compares the shear-stress-displacements curves measured by the DSTs with the 436 numerical results obtained by the numerical modelling technique. Figure 6 shows the shear437 stress-displacement curves at normal stresses of 50, 100, and $150 \mathrm{kPa}$ for the six interfaces I1-I6. 438 Table 3 summarizes the difference between the DST results and the numerical results for $100 \mathrm{kPa}$ 439 normal stress and for two levels of relative shear displacements (10 $\mathrm{mm}$ and $40 \mathrm{~mm})$.

441 The results reported in Figure 6 and Table 3 provide clear evidence that, for all six interfaces, the 442 numerical model properly predictd shear behaviour. The numerical modelling results were 443 comparable with the experimental results. In addition, this result holds for all levels of confining 444 stress and for all relative shear displacements. Below we describe the results for the six interfaces 445 obtained for $100 \mathrm{kPa}$ normal stress and at $50 \mathrm{~mm}$ relative shear displacements.

446 Consider first interface I1 (sand-GTX) at $100 \mathrm{kPa}$ normal stress and $50 \mathrm{~mm}$ relative shear 447 displacement. The interface shear stress measured by using the DST was $61.8 \mathrm{kPa}$ and the shear 448 stress obtained by using the numerical model was $60.3 \mathrm{kPa}$; a difference of only $1.5 \mathrm{kPa}(2.4 \%)$. 449 For interface I2 (GTX-GMB) at a $100 \mathrm{kPa}$ normal stress and $50 \mathrm{~mm}$ relative shear displacement, 450 the interface shear stress measured by using the DST was $12.1 \mathrm{kPa}$ and the shear stress obtained 451 by using the numerical model was $13.7 \mathrm{kPa}$; a difference of only $1.6 \mathrm{kPa}(13.2 \%)$. For interface 
$452 \mathrm{I} 3$ (GMB-GCL) at $100 \mathrm{kPa}$ normal stress and $50 \mathrm{~mm}$ relative shear displacement, the difference

453 between the measured shear stress $(16.0 \mathrm{kPa})$ and the calculated shear stress (15.8 $\mathrm{kPa})$ was only

$454 \quad 0.2 \mathrm{kPa}$; a difference of only $1.6 \mathrm{kPa}(-1.3 \%)$. At interface I4 (GCL-sand), the difference

455 between the measured shear stress $(62.9 \mathrm{kPa})$ and the calculated shear stress $(61.3 \mathrm{kPa})$ was 1.6

$456 \mathrm{kPa}(-2.5 \%)$. Finally, at interfaces I5 and I6 (GGR-sand), the shear stress measured by using the

457 DST was $61.4 \mathrm{kPa}$ and the shear stress obtained from the numerical model was $63.5 \mathrm{kP}$; a

458 difference of only $0.9 \mathrm{kPa}(-1.5 \%)$. These results demonstrate that the numerical modelling

459 technique used to simulate the strain-softening behaviour of interfaces accurately describes the

460 shear behaviour of the six interfaces.

461

$462 \quad 6.3$ Large-scale test

464 Figure 9 shows the overall deformed shape of the reinforced lining system within the LSTA for

$465100 \mathrm{kPa}$ confining pressure. Experiment and numerical model both exhibit a similar overall

466 deformed shape, which is evidence that the results of the numerical model are reasonable and that

467 it properly simulates the overall mechanical behaviour of the reinforced lining system. To deepen

468 the analysis and show the relevance of the numerical model, the strains within the GGR and the

469 GMB are analyzed.

470 To measure strain, a MSG was attached at the center of the cavity on both sides (lower and

471 upper) of the GGR and of the GMB. The mean strain was then obtained and the corresponding

472 error bar was determined. Figure 10a compares the strains measured within the GGR by using the

473 MSGs (Experiment) and the strains calculated by using the numerical model. The same 
474 comparison is made in Figure 10b for the GMB. Various values derived from these figures are

475 grouped in Table 4.

476

477 For the GGR, the strains obtained by using the numerical model always fall within the

478 experimental error bars (Figure 10a), which indicate the variability of the measured strains. The

479 agreement is particularly good for strains below $1 \%$ (i.e., below $30 \mathrm{kPa}$ ) and above $2 \%$ (i.e.,

480 above $60 \mathrm{kPa}$ ). For example, at $10 \mathrm{kPa}$ applied load, the strain measured within the GGR was

$481 \quad 0.37 \%$ and the strain obtained by using the numerical method was $0.46 \%$; a difference in strain of

482 only $-0.09 \%$. At $100 \mathrm{kPa}$, the analogous strain difference was $-0.04 \%$ (2.53\% strain from

483 experiment and $2.57 \%$ strain from numerical model). The maximum strain difference of $0.38 \%$

484 between the measured and calculated strains occurred at $40 \mathrm{kPa}$. These results demonstrate that

485 the numerical model accurately predicts strains whatever the applied load.

487 Although the agreement was less impressive for the GMB than for the GGR, it remains

488 acceptable. The maximum strain difference between the measured and calculated strains was only

$4890.30 \%$ of strain (at $30 \mathrm{kPa})$. Note that the accuracy of the numerical result increased in particular

490 for strains above $1 \%$ (above $50 \mathrm{kPa}$ ). For example, at $100 \mathrm{kPa}$, the measured strain was $1.74 \%$

491 and the calculated strain was $1.65 \%$, a strain difference of only $0.09 \%$.

492

493 These results show that the numerical modelling technique accurately predicts both the overall

494 deformed shape of the reinforced lining system and the strains within both the GGR and the 495 GMB. 


\section{CONCLUSIONS}

499 Numerical modelling can be used to aid in the design of geotechnical constructions involving

500 geosynthetics (geosynthetics), such as landfills. However, the reliability of the numerical results

501 depends on how the model is developed and on the parameter set that is used.

502 The present work develops a procedure to analyze multilayered-lining systems by using a 2D

503 finite-difference method. The accuracy of this numerical modelling technique is then verified by

504 comparing its results with those obtained experimentally by using uniaxial tests, direct-shear tests

505 and a specific large-scale test. The large-scale test involved a reinforced lining system spanning

506 over a cavity and made of a $50 \mathrm{kN} / \mathrm{m}$ polyvinyl alcohol geogrid (GGR) reinforcement embedded

507 in a sand layer, a geosynthetic clay liner (GCL), a high-density polyethylene geomembrane

508 (GMB), and a nonwoven needle-punched geotextile (GTX). All three experimental tests were

509 modelled by using the given numerical modelling technique and the numerical results were

510 compared with the experimental results. These comparisons lead to the following conclusions:

512 (a) The tensile curves obtained from the uniaxial tensile tests closely match those obtained from

513 the numerical model, and this good agreement occurred for the four geosynthetics (GGR, GCL,

514 GMB, and GTX) and for all levels of strain. This verifies that the numerical modelling technique

515 provides an accurate description of the evolution with strain of the stiffness within the 516 geosynthetics.

518 (b) The shear behaviour of the interfaces obtained from the numerical model closely match those 519 obtained experimentally by using direct shear tests, and this high accuracy occurred for all 
520 interfaces, at all levels of the confining stress, and for all relative shear displacements at the given

521 interface. These results indicate that the numerical modelling technique considering the strain-

522 softening behaviour of interfaces accurately describes the shear behaviour of the geosynthetic

523 interfaces.

525 (c) Considering the multiple interactions between the four geosynthetics that spanned over a

526 cavity in the large-scale test apparatus, the experimentally observed overall deformation of the

527 reinforced lining system was successfully described by the numerical model. At the center of the

528 cavity, a close match also occurred between the measured and calculated strains within the GGR

529 and GMB. This result verifies that the numerical modelling technique that was developed in this

530 work gives accurate predictions.

531 This ensemble of results verifies the accuracy of this numerical modelling technique and allows it

532 to be used with confidence to predict the mechanical behaviour of multilayered geosynthetic

533 lining system over a cavity.

535 Finally, although a large-scale test and multiple interactions between geosynthetics were

536 considered in developing this numerical modelling technique, this technique could benefit from

537 further verification; namely, by comparing its results against those of full-scale measurements

538 particularly from geosynthetic lining system on slopes. Furthermore, it would also be interesting

539 to study whether the use of confined UTTs or multiaxial tensile tests can increase the reliability

540 of this numerical modelling technique developed in this study. 


\section{AKNOWLEDGMENTS}

543

544 The authors thank Didier Croissant (Irstea, Antony, France) and P. Mailler (IFTH, France) for

545 their assistance during in carrying out the various tensile tests. Special thanks are also due to $\mathrm{H}$.

546 Mora and J.-M. Miscioscia (LTHE, Grenoble, France) for manufacturing the large-scale

547 experiment apparatus used in this study. Finally, the authors thank J. Bruhier at Huesker, France

548 for providing us with the geogrid, geotextile, and geosynthetic clay liner products used in this

549 study.

550 9. REFERENCES

551

552

553

554

555

556

557

558

559

560

561

562

563

564

565

566

567

568

569

570

571

572

573

574

575

576

577

AFNOR (1996) NF P94-056 : Sols - reconnaissance et essais - Analyse granulométrique Méthode par tamisage à sec après lavage.

AFNOR (2005a) NF EN ISO 9862 : Géosynthétiques - Échantillonnage et préparation des éprouvettes. $5 \mathrm{p}$.

AFNOR (2005b) NF EN ISO 9864 : Géosynthétiques - Méthode d'essai pour la détermination de la masse surfacique des géotextiles et produits apparentés.

AFNOR (2008) NF EN ISO 10319 : Géosynthétiques - Essai de traction des bandes larges.11 p p. AFNOR (2013) NF EN 12311-2 : Feuilles souples d'étanchéité - Détermination des propriétés en traction - Partie 2 : Feuilles d'étanchéité de toiture plastiques et élastomères. $9 \mathrm{p}$.

AFNOR (2010) NF EN 1849-1/2 : Feuilles souples d'étanchéité - Détermination de l'épaisseur et de la masse surfacique - Partie 2 : feuilles d'étanchéité de toiture plastiques et élastomères. AFNOR (2016a) NF EN ISO 9863-1 : Géosynthétiques - Détermination de l'épaisseur à des pressions spécifiées - Partie $1:$ couches individuelles.

AFNOR (2016b) NF EN 14196 : Géosynthétiques - Méthodes d'essai pour la détermination de la masse surfacique des barrières géosynthétiques argileuses bentonitiques.

Byrne, R.J. (1994) Design issues with strain-softening interfaces in landfill liners. Proc. of the Waste Technology 94, Charleston, South Carolina, USA, Session 4,Paper 4. 26 p.

Chen, Y.-M., Gao, D., Zhu, B. (2009b) Controlling strain in geosynthetic liner systems used in vertically expanded landfills. Journal of Rock Mechanics and Geotechnical Engineering 2009. 1(1) 48-55.

Connell, A.C. (2002) Factors controlling the waste/barrier interaction with specific consideration to the integrity of steep-sided landfill lining systems. Department of Civil and Building Engineering, Loughborough University. Loughborough University internal report submitted in partial fulfilment of transfer from MPhil to $\mathrm{PhD}$.

Fowmes, G.J., Jones, D.R.V., Dixon, N. (2005b) Analysis of a landfill directive compliant steepwall lining system. Proc. of the 10th International Waste Management and Landfill Symposium, Sardinia, S. Margherita di Pula, Cagliari, Italy, pp. 369. 
Fowmes, G.J., Dixon, N., Jones, D.R.V. (2008) Validation of a numerical modelling technique for multilayered geosynthetic landfill lining systems. Geotextiles and Geomembranes 26 109-

580121.

581 Giroud, J.P. (1994) Mathematical model of geomembrane stress-strain curves with a yield peak. Geotextiles and Geomembranes. 13(1) 1-22. Giroud, J.P., Beech, J.F., (1989) Stability of soil layers on geosynthetic lining system. Proc. of the Geosynthetics Conference, San Diego, USA, pp. 35-46.

Girout, R., Blanc, M., Dias, D., Thorel, L. (2014) Numerical analysis of a geosyntheticreinforced piled load transfer platform - Validation on centrifuge test. Geotextiles and Geomembranes. 42(5) 525-539.

Hicher, P.-Y. (1998) Behavior of granular materials. Bernard Cambou - Central School of Lyon, $405 \mathrm{p}$.

Itasca (2005) FLAC Version 5, Fast Lagrangian Analysis of Continua, Online Manual Table of Contents. 3058 p.

Jewell, R.A., Milligan, G.W.E., Sarsby, R.W., Dubois, D. (1984) Interaction between soil and geogrids. Proc. of the Symposium on Polymer Grid Reinforcement in Civil Eng, London, U.K., pp. 19-29.

Jones, D.R.V., Dixon, N. (2005) landfill lining stability and integrity: the role of waste settlement. Geotextile and Geomembranes. 23 27-53.

Kezdi, A. (1974) Handbook of Soil Mechanics. Elsevier, Amsterdam. 258 p.

599

Koerner, R.M., Hwu, B.-L. (1991) Stability and tension considerations regarding cover soils on geomembrane lined slopes. Geotextiles and Geomembranes. 10(4) 335-355.

600 Lajevardi, S.H., Briançon, L., Dias, D. (2014) Experimental studies of the geosynthetic

601 anchorage - Effect of geometric parameters and efficiency of anchorages. Geotextiles and

602 Geomembranes. 42(5) 505-514.

603 Obrzud, R.and Truty, A. (2012) The Hardening Soil model - a practical guidebook. Technical

604 report. Z_Soil.PC 100701, Zace Services Ltd, Lausanne, 93 p.

605 Prat, M., Bisch, E., Millard, A., Mestat, P., and Cabot, G. (1995). La modélisation des ouvrages.

606 Collection emploi des éléments finis en genie-civil. Hermes, Paris. 778 p.

607 Tano, F., Olivier, F. (2014) Use of geosynthetics in piggy-back landfills: development of an

608 iterative methodology for the design of the lining system over old unlined waste. Proc. of the

609 10th ICG 2014, September 21-25, Berlin, Germany. 8 p.

610 Tano, F., Olivier, F., Touze-Foltz, N., Dias, D. (2015) State-of-the-art of piggy-back landfills

611 worldwide: comparison of containment barrier technical designs and performance analysis in

612 terms of geosynthetics stability. Proc. of the Geosynthetics 2015, February 15-18, Portland,

613 Oregon, USA. $11 \mathrm{p}$.

614

615

616

Tano, B.F.G., Dias, D., Fowmes, G.J., Olivier, F., Stoltz, G., Touze-Foltz, N. (2016a) Numerical modeling of the nonlinear mechanical behaviour of multilayer geosynthetic system for piggyback landfill expansion. Geotextiles and Geomembranes. 44(6) 782-798.

620 
623 Wesseloo, J., Visser, A.T., Rust, E. (2004) A mathematical model for the strain-rate dependent 624 stress-strain response of HDPE geomembranes. Geotextiles and Geomembranes. 22 273-295.

625 Zamara, K.A., Dixon, N., Fowmes, G., Jones, D.R.V., Zhang, B. (2014) Landfill side slope lining 626 system performance: A comparison of field measurements and numerical modelling analyses.

627 Geotextiles and Geomembranes. 42(3) 224-235.

628 Zhu, B., Gao, D., Chen, Y.-M. (2009) Geomembrane tensions and strains resulting from

629 differential settlement around rigid circular structures. Geotextiles and Geomembranes. 27(1) 53-

63062.

631

632

633 
Table 1. Summary of material, geosynthetic, and interface properties.

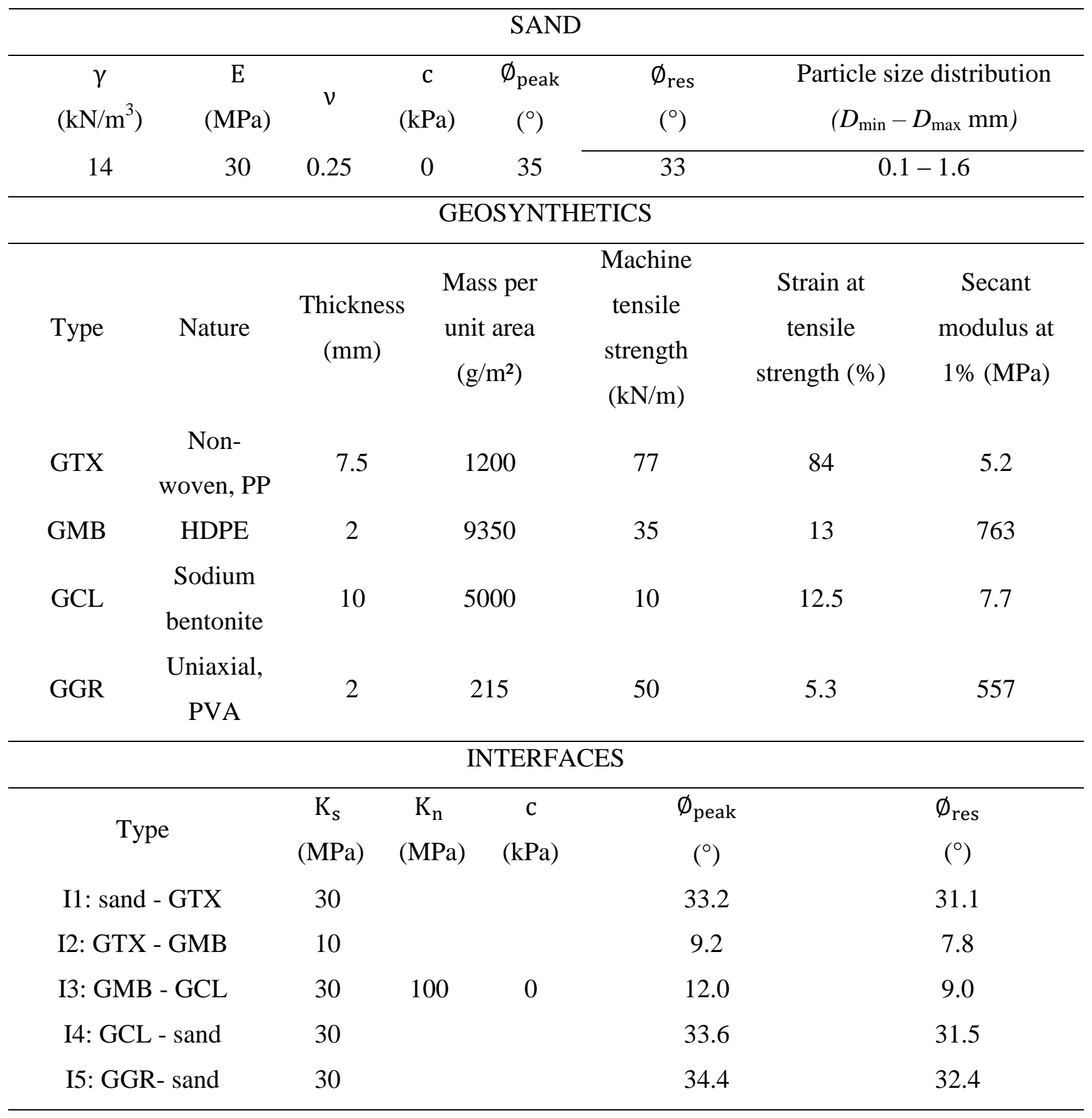


636 Table 2. Comparison of results of uniaxial tensile test with results of numerical model.

\begin{tabular}{|c|c|c|c|c|c|c|c|c|}
\hline \multirow{3}{*}{$\begin{array}{c}\text { Force within the } \\
\text { geosynthetics }(\mathrm{kN}) \\
\text { using : }\end{array}$} & \multicolumn{8}{|c|}{ Strain within the geosynthetics } \\
\hline & \multicolumn{4}{|c|}{$2 \%$} & \multicolumn{4}{|c|}{$4 \%$} \\
\hline & GTX & GMB & GCL & GGR & GTX & GMB & GCL & GGR \\
\hline Uniaxial tensile test & 0.7 & 22.2 & 1.8 & 18.2 & 1.4 & 29.6 & 4.2 & 38.6 \\
\hline Numerical model & 0.6 & 21.3 & 2.0 & 16.4 & 1.2 & 29.0 & 4.5 & 37.9 \\
\hline
\end{tabular}


638 Table 3. Comparison of results of direct shear test with results of numerical model at $100 \mathrm{kPa}$ normal stress.

\begin{tabular}{|c|c|c|c|c|c|c|c|c|c|c|}
\hline & \multicolumn{10}{|c|}{ Relative shear displacement at interface } \\
\hline & \multicolumn{5}{|c|}{$10 \mathrm{~mm}$} & \multicolumn{5}{|c|}{$50 \mathrm{~mm}$} \\
\hline $\begin{array}{c}\text { Shear stress at } \\
\text { interface }(\mathrm{kPa}) \\
\text { using : }\end{array}$ & $\mathrm{I} 1$ & $\mathrm{I} 2$ & $\mathrm{I} 3$ & I4 & I5\&I6 & I1 & $\mathrm{I} 2$ & $\mathrm{I} 3$ & $\mathrm{I} 4$ & I5\&I6 \\
\hline $\begin{array}{c}\text { Direct shear } \\
\text { test }\end{array}$ & 58.2 & 14.3 & 16.3 & 58.9 & 49.1 & 61.8 & 12.1 & 16.0 & 62.9 & 61.4 \\
\hline $\begin{array}{c}\text { Numerical } \\
\text { model }\end{array}$ & 58.1 & 14.8 & 17.1 & 58.1 & 50.2 & 60.3 & 13.7 & 15.8 & 61.3 & 63.5 \\
\hline
\end{tabular}


Table 4. Comparison of results of large-scale test with results of numerical model.

\begin{tabular}{|c|c|c|c|c|c|c|}
\hline \multirow[b]{2}{*}{ Applied load (kPa) } & \multicolumn{3}{|c|}{ Geogrid } & \multicolumn{3}{|c|}{ Geomembrane } \\
\hline & 10 & 50 & 100 & 10 & 50 & 100 \\
\hline \multicolumn{7}{|c|}{ Strains (\%) at the center of } \\
\hline \multicolumn{7}{|l|}{ cavity using: } \\
\hline Large-scale test & 0.37 & 1.88 & 2.53 & 0.45 & 1.23 & 1.74 \\
\hline Numerical model & 0.46 & 1.54 & 2.57 & 0.32 & 0.99 & 1.65 \\
\hline
\end{tabular}

642

643 


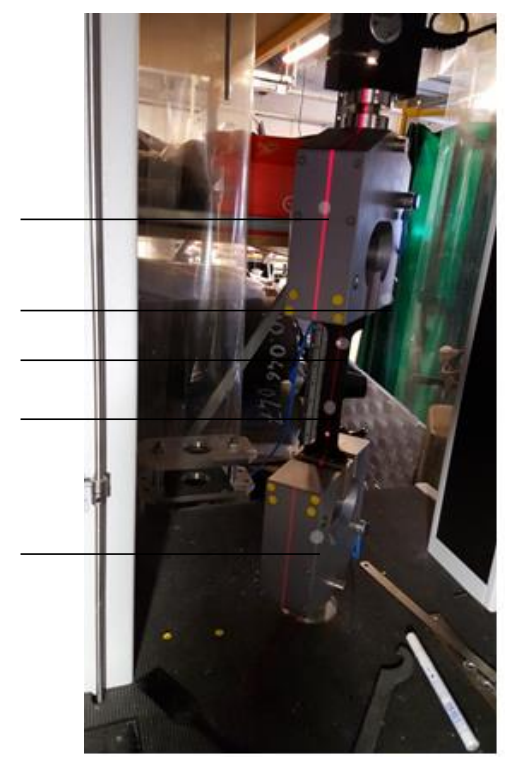

Figure 1. Tensile test device used in this study. 


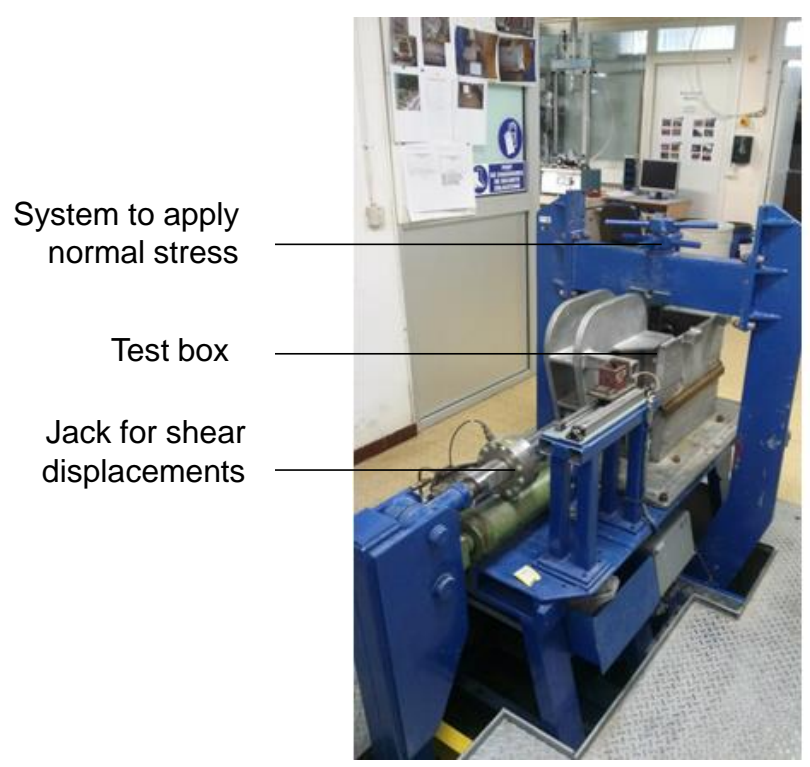

Figure 2. Direct shear test device used in this study. 


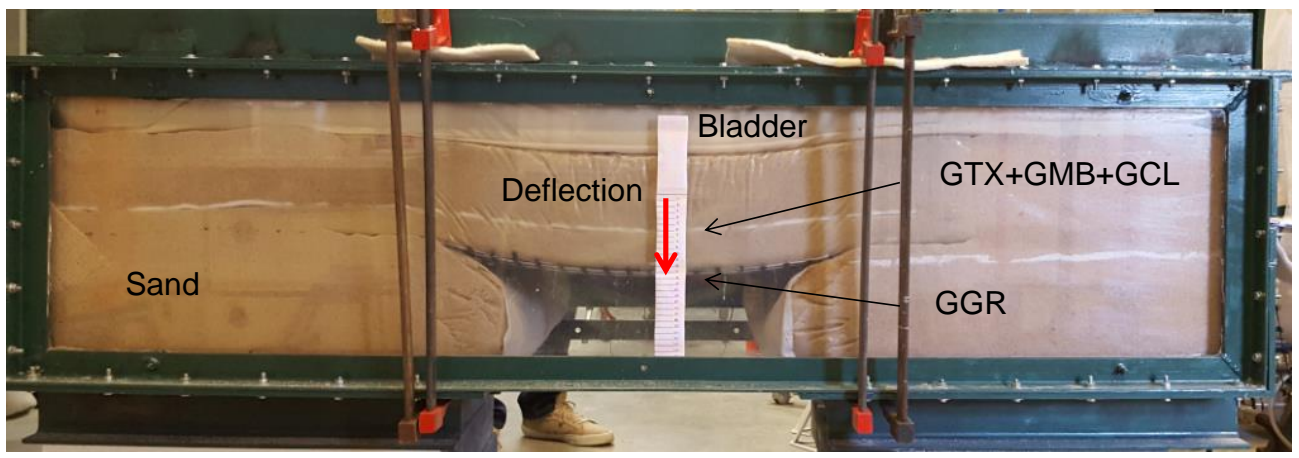

Figure 3. Large-scale test apparatus to simulate a cavity. 
(a)

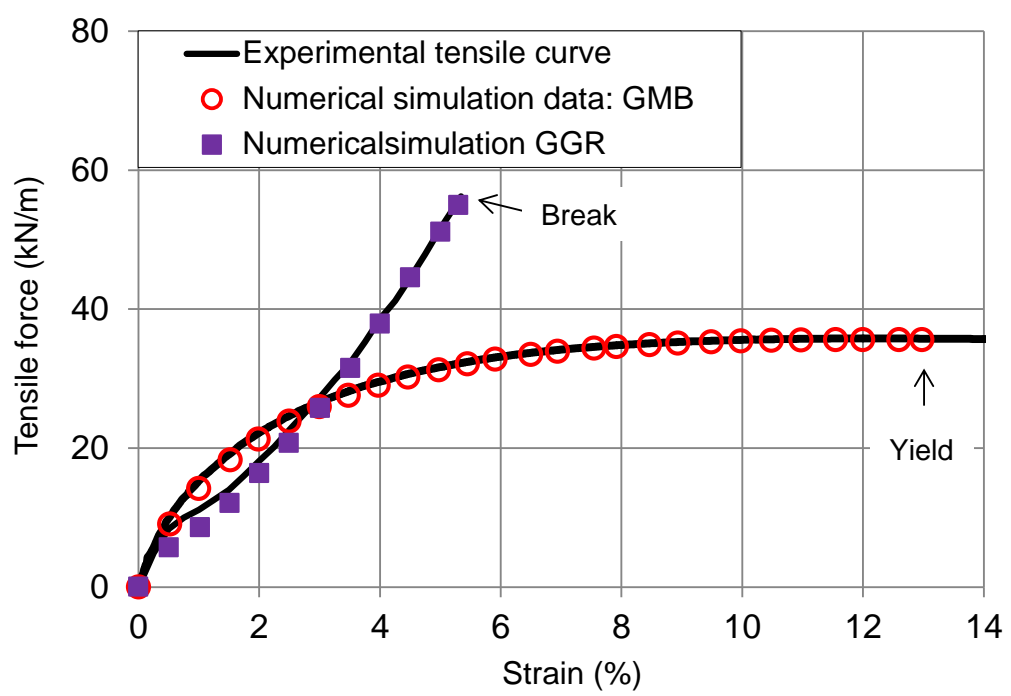

(b)

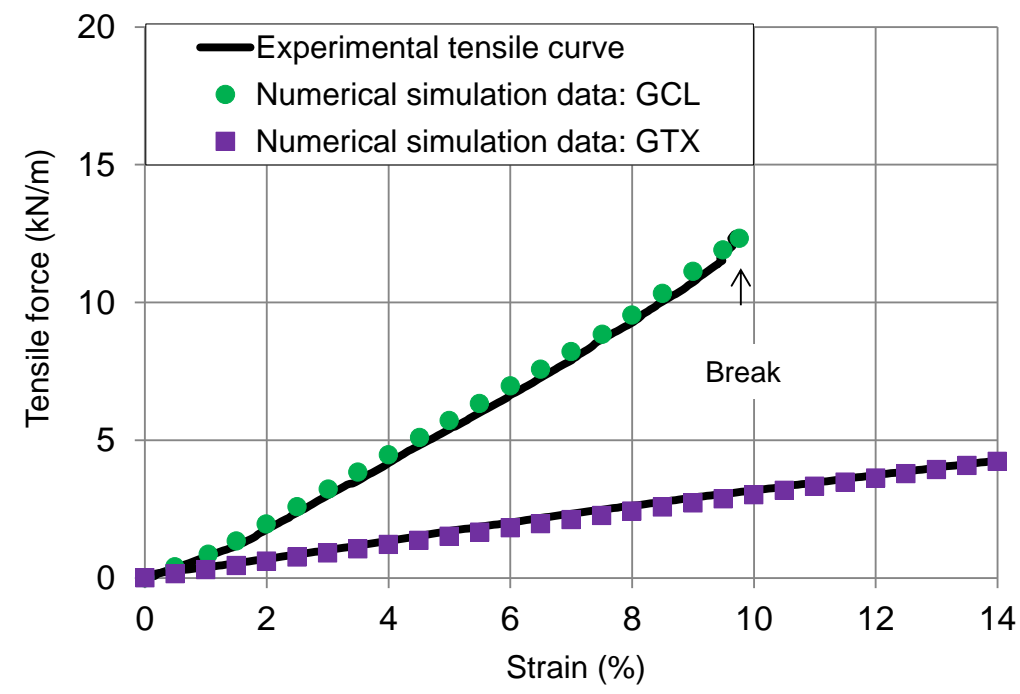

656 Figure 4. Tensile force vs strain measured by uniaxial tensile tests (solid curves) and compared

657 with results of numerical simulation (symbols) for (a) geomembrane and geogrid, and (b)

658 geosynthetic clay liner and geotextile.

659 
(a)

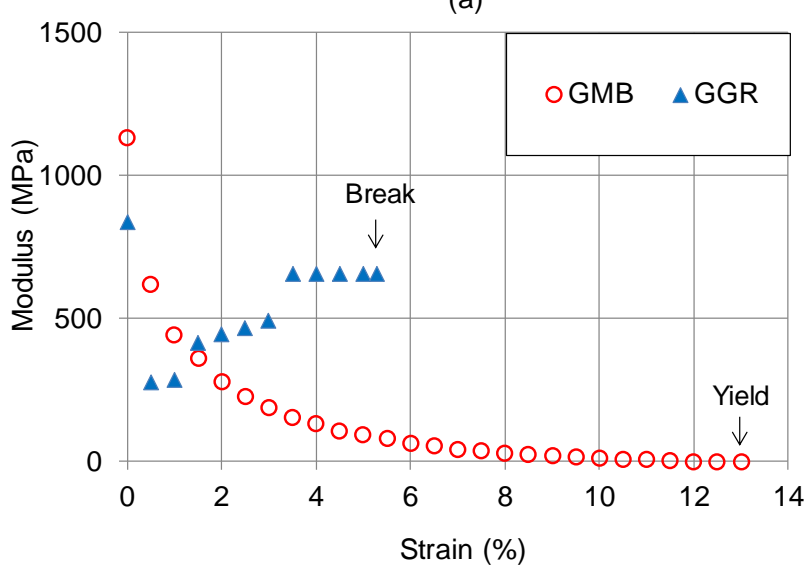

(b)

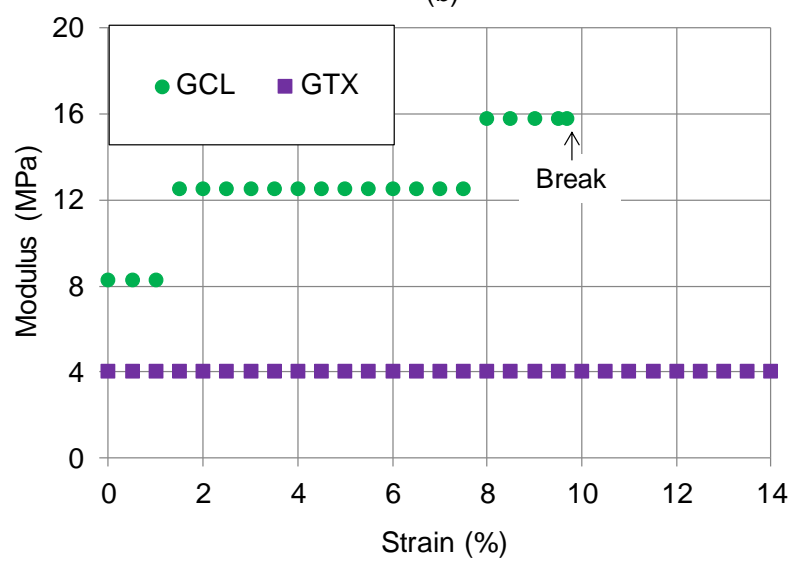

Figure 5. Modulus of geosynthetic versus strain for (a) geomembrane and geogrid and (b) geosynthetic clay liner and geotextile. 

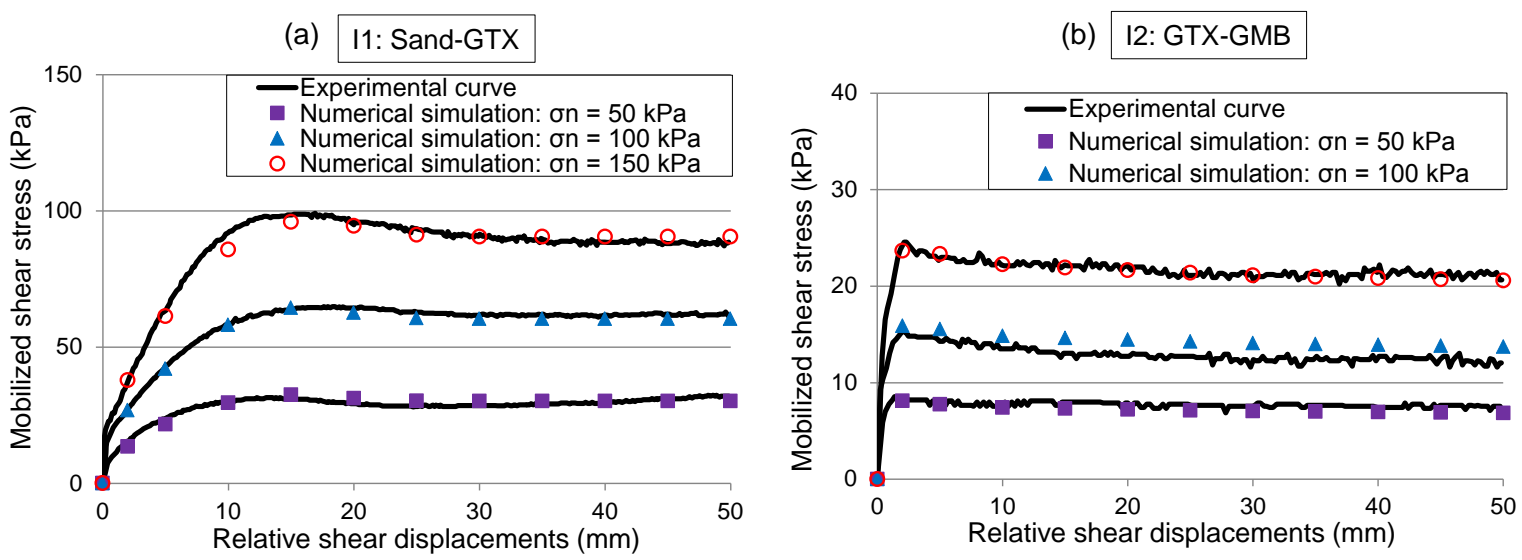

(c) I3: GMB-GCL

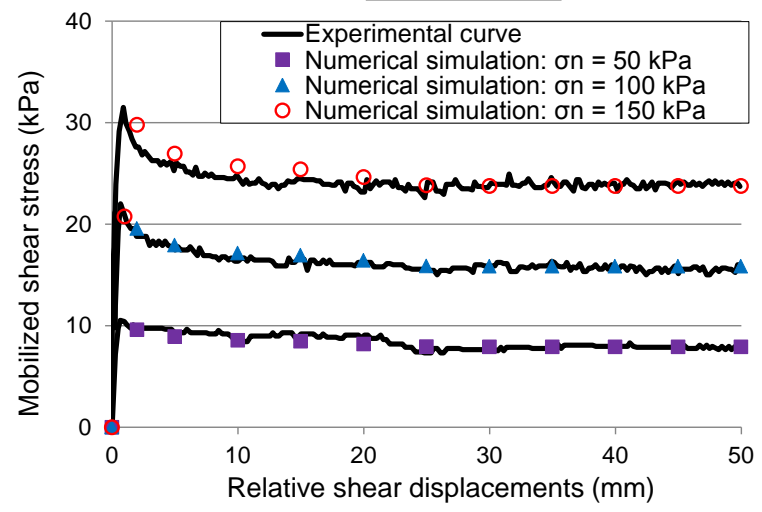

(d) 14: GCL-Sand

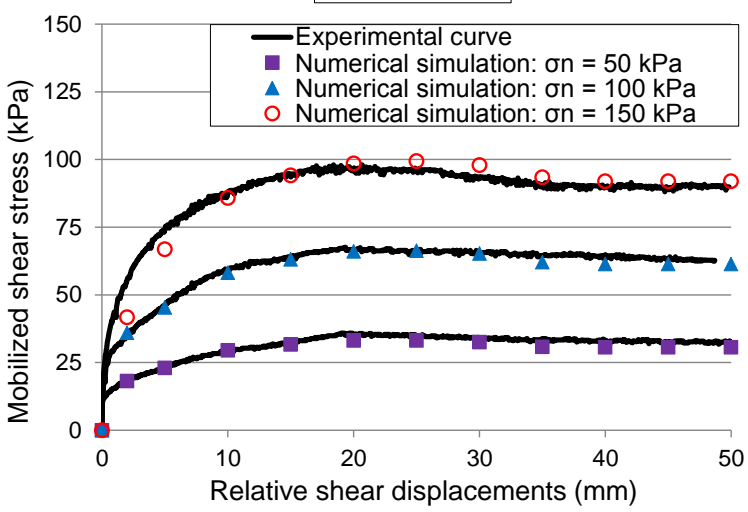

(e) I5\&I6: GGR-Sand

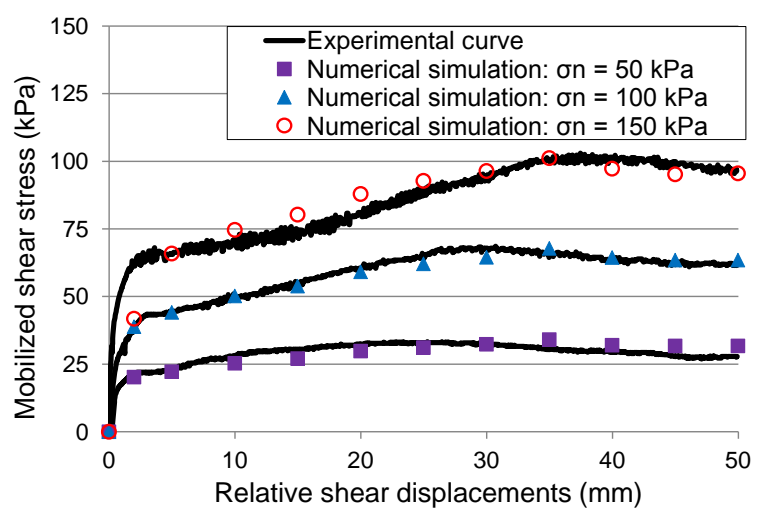

664 Figure 6. Shear stress vs relative shear displacement measured by direct shear tests (solid curves)

665 and compared with results of numerical simulation (symbols) for the following interfaces: (a)

666 sand-GTX (I1). (b) GTX-GMB (I2), (c) GMB-GCL (I3), (d) GCL-sand (I4), (e) GGR-sand (I5, 
(a)

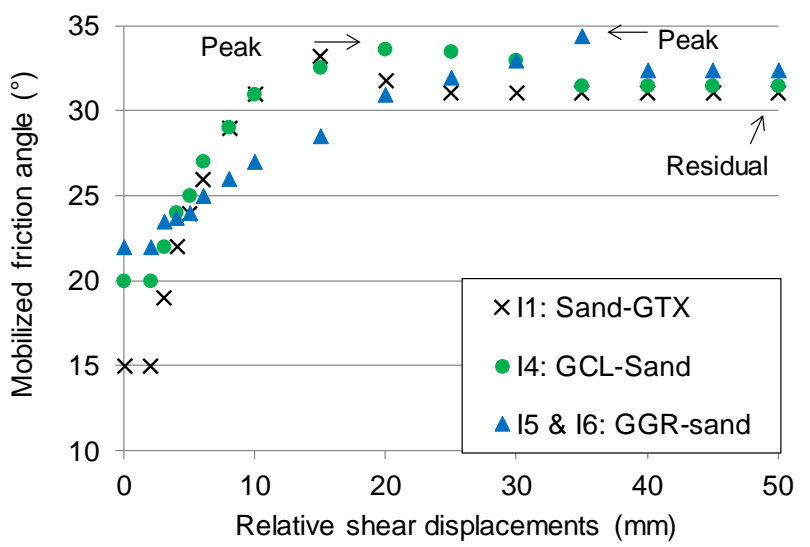

(b)

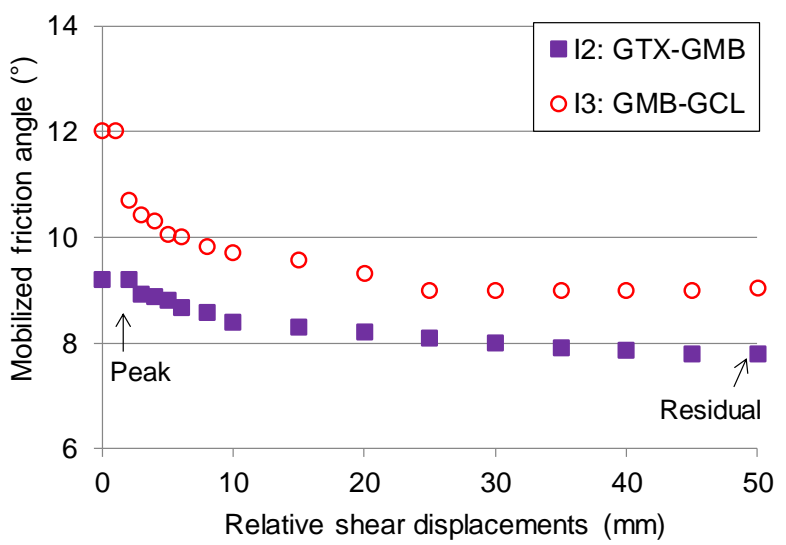

669 Figure 7. Mobilized friction angle versus interface displacement for the following interfaces: (a)

670 sand-geotextile (I1), geosynthetic clay liner-sand (I4), geogrid-sand (I5, I6) and (b) geotextile-

671 geomembrane (I2) and geomembrane-geosynthetic clay liner (I3). 

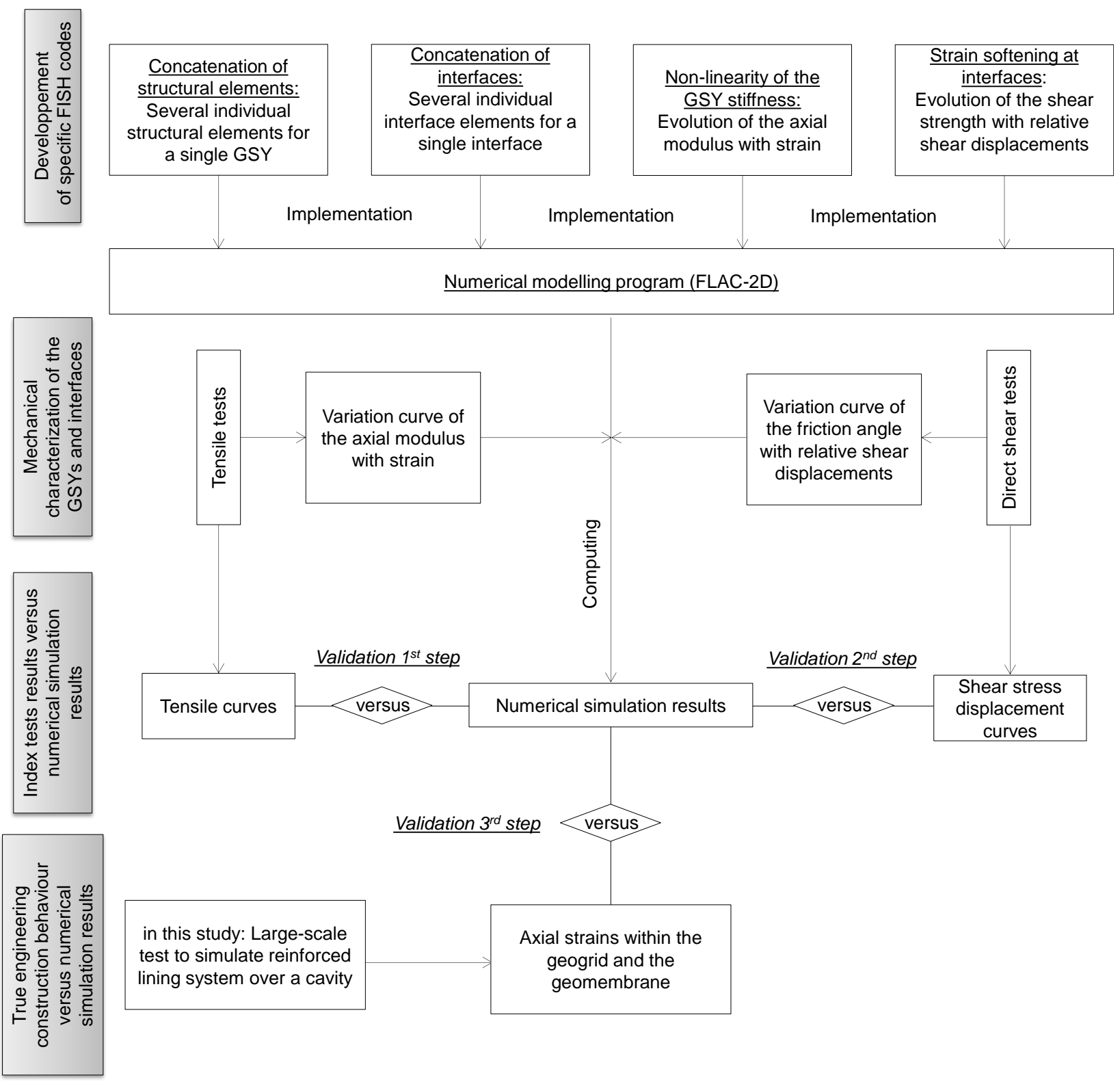

in this study: Large-scale test to simulate reinforced lining system over a cavity

Axial strains within the geogrid and the geomembrane

675 Figure 8. Procedure used to verify the numerical modelling technique. 
(a)

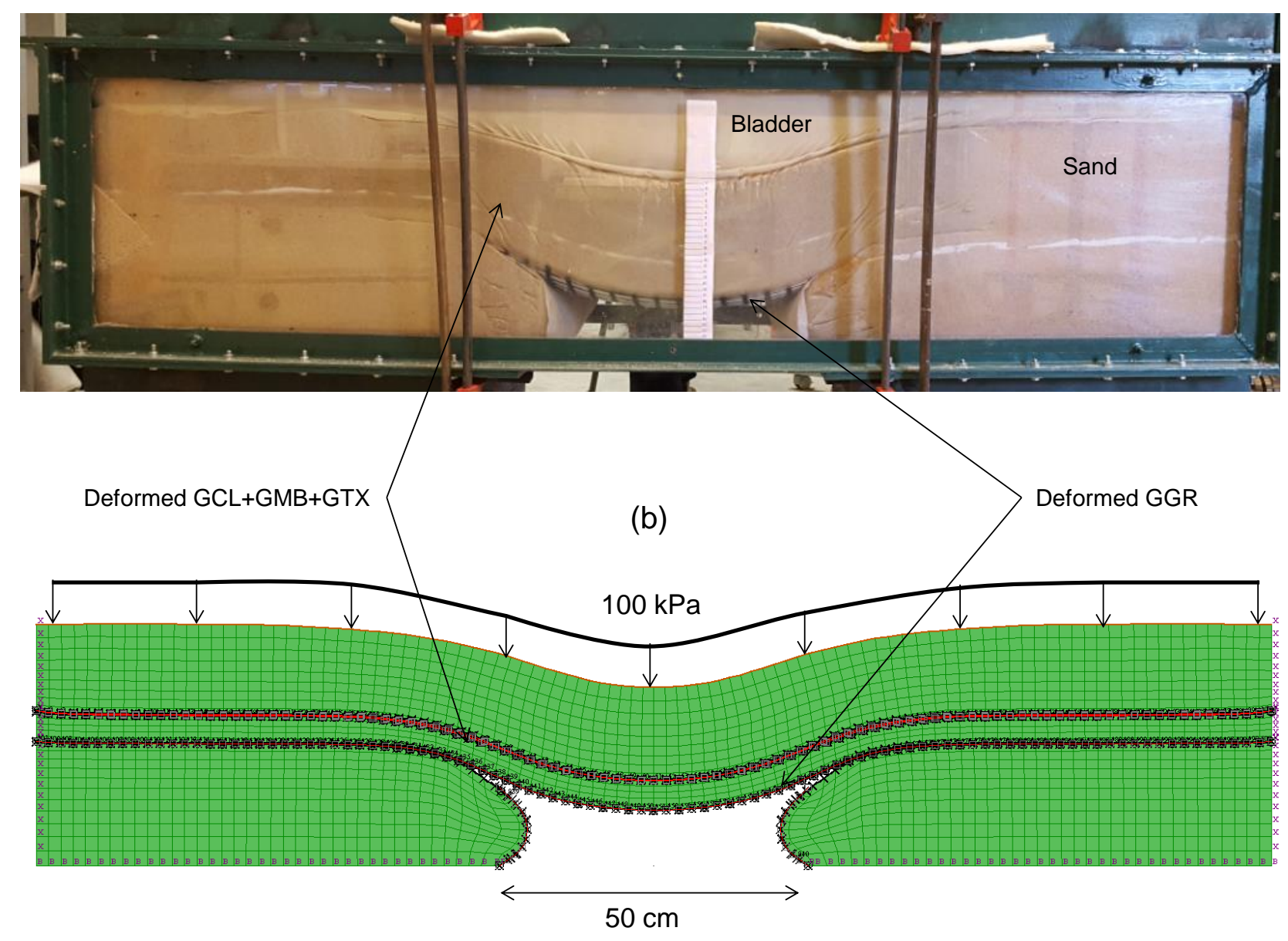

678 Figure 9. Overall deformed shape of the reinforced lining system with $100 \mathrm{kPa}$ confining

679 pressure: (a) experimental results, (b) numerical results. 
(a)

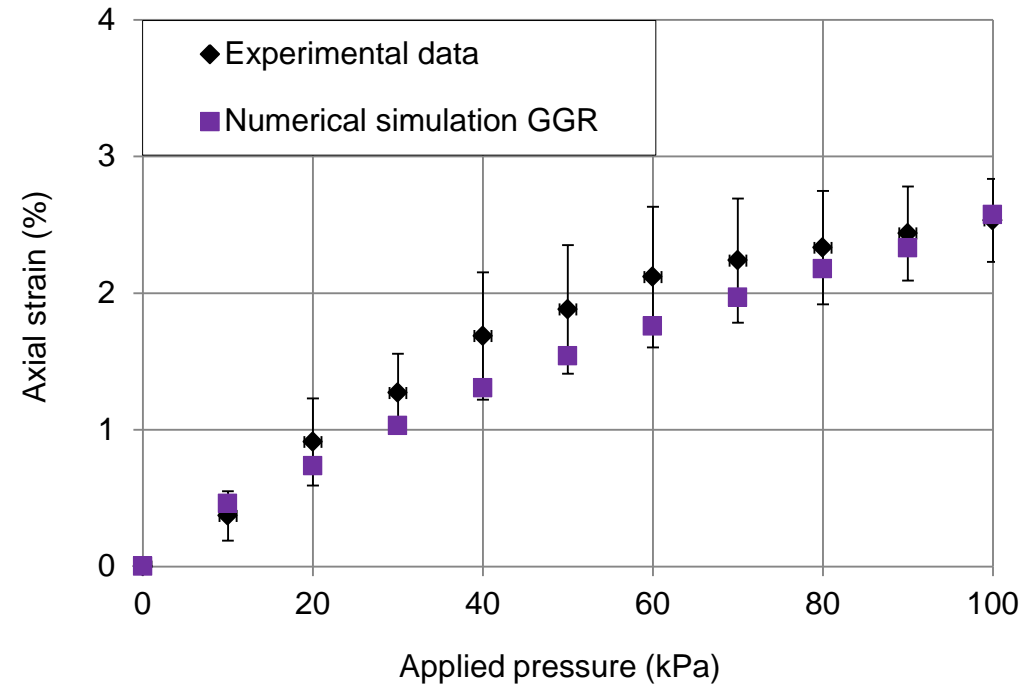

(b)

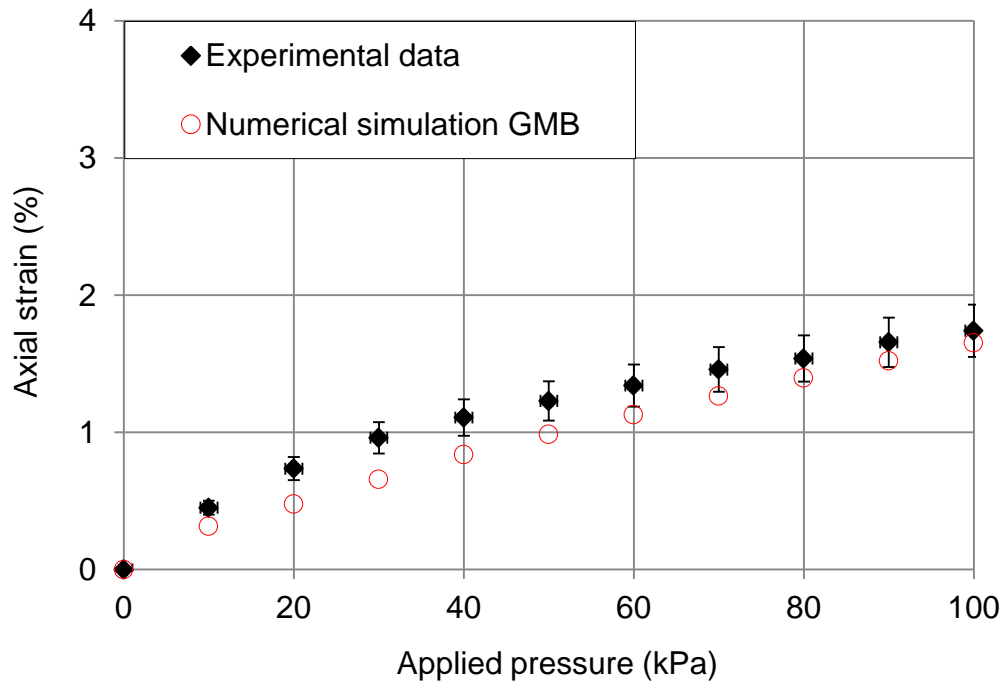

680

681 Figure 10. Axial strains within the geosynthetics measured by microstrain gauges vs applied 682 pressure and compared with results of numerical simulation for (a) geogrid and (b) 683 geomembrane. 